\title{
Maciej Mielnik
}

Uniwersytet Stambulski

\section{Słowiańskie ‘da’ i jego bałkańska specyfika}

Analiza materiału językowego w słownikach zwraca uwagę na rozległy charakter użycia $d a$ w słowiańszczyźnie. Sytuacja ta nie dotyczy wszystkich języków w takim samym stopniu. O ile prasłowiańskie i staro-cerkiewno-słowiańskie $d a$ było elementem niezwykle wielofunkcyjnym, współcześnie tylko języki diasystemu serbsko-chorwackiego i grupy bułgarsko-macedońskiej kontynuują te formy w sposób rozległy. Pozostałe języki grupy słowiańskiej zachowały tylko niektóre derywaty lub ograniczyły funkcję da do partykuły twierdzącej.

\section{1. 'Da' ogólnosłowiańskie}

Słowniki języka prasłowiańskiego oraz staro-cerkiewno-słowiańskiego w sposób szczegółowy opisują $d a$ jako partykułę potwierdzającą, ekspresywną, wzmacniającą, uwydatniającą, a także modalną życzącą, która służy tworzeniu

This work has been prepared at author's own expense.

Competing interests: no competing interests have been declared.

Publisher: Institute of Slavic Studies, Polish Academy of Sciences.

This is an Open Access article distributed under the terms of the Creative Commons Attribution 3.0 PL License (creativecommons.org/licenses/by/3.0/pl/), which permits redistribution, commercial and non-commercial, provided that the article is properly cited. (c) The Author(s) 2018. 
trybu rozkazującego. $\mathrm{Da}$ interpretowane jest jako spójnik łączny, przeciwstawny lub hipotaktyczny, który wprowadza zdania przedmiotowe, celowe, warunkowe, skutkowe i przyzwolone (por. Sadnik \& Aitzetmüller, 1955, s. 18; Sławski, 1976, s. 323; Znosko, 1996, s. 83). Oprócz tego partykuła może jeszcze oznaczać „повелительное наклоненіе при глаголахъ будущаго времени, np. И рече Богъ: да будетъ свътъ, и бысть свЂтъ. Да препояшетъ радость холмы” (Поленов, 1847, s. 304).

Staro-cerkiewno-słowiańskie $d a$ (wyjątkowo przed $i$ przybierające formę do) wyrażało zachętę i pobudzenie ('więc', 'nuże'). Poza funkcjami partykuły potwierdzającej, wzmacniającej, spójnika parataktycznego, hipotaktycznego i w funkcji pytajno-wzmacniającej, $d a$ tworzyło tryb rozkazujący lub życzący, najczęściej dla 3. os. sg. i pl.

Warto zwrócić uwagę również na wyraz do. Ten „wskazujący granicę, kres czynności, zjawiska w przestrzeni, w czasie, pod względem ilości i sposobu" przyimek, kontynuując indoeuropejskie do i bałtosłowiańskie $d a$ (od pierwiastka zaimkowego de- : do-, który tworzył podstawę różnych partykuł), nawiązywać ma do da oraz jego licznych derywatów (Sławski, 1976, s. 280).

Słowiańskie $d a$ : do łączyć się miało z partykułą wzmacniającą -že w formy daže : dože (cecha południowo-wschodniej słowiańszczyzny). Słowa te znaczeniowo odpowiadają polskiemu 'nawet' (jako spójnik nawiązujący 'nawet i'), natomiast użyte dla wyrażenia kresu czegoś $w$ przestrzeni lub czasie oznaczają 'aż' (w tym znaczeniu często z przyimkiem do - daže do, dože do); również jako spójnik czasowy oznaczać mogą 'do czasu aż', 'dopóki' lub 'zanim' (Sławski, 1979, s. 25) ${ }^{1}$.

Słownik prasłowiański wyróżnia również hasło de: dě. Klasyfikowane jako partykuła wzmacniająca, podkreślająca (zwłaszcza rozkaz, polecenie), pobu$d z a j a ̨ c a$, podobnie jak $d a$, tworzy zaimki i przysłówki nieokreślone (w języku słowińskim pod postacią ze-; $\mathrm{w}$ dolnołużyckim - źe lub źo) ${ }^{2}$. Formy de : dě występują również (analogicznie do daže i dože) pod postacią deže ${ }^{3}$.

${ }^{1}$ Forma dože w języku starosłoweńskim przybrała formę dožda; jako partykuła potwierdzająca występowała również w dialektach pod postacią dòr (Sławski, 1979, s. 25).

2 Dolnołużyckie źe i źo (również źen, źem, źé, źém; w górnołużyckim - dźe) jest partykuła wzmacniającą w zdaniach wyrażających życzenie lub rozkaz: spojź źe! ('spójrzże!') lub cakajźo źen! ('czekajżeż!') (Sławski, 1979, s. 26).

${ }^{3}$ Dla języka słoweńskiego poświadczono formę dèr, dla serbsko-chorwackiego zaś - dèr, dëre, dëder. Również derywaty inzde, kzde, onzde, ovøde, søde, tzde mają zawierać w sobie partykułę de : dě (Sławski, 1979, s. 26). 


\section{Etymologia}

Badacze sugerują indoeuropejsko-greckie pochodzenie $d a^{4}$. Słowo to postrzega się w językach słowiańskich jako kontynuant indoeuropejskiego dō (do-/di-) o znaczeniu 'do tego', 'tu'. Tę samą indoeuropejską podstawę ma też zawierać łacińskie de. Słowiańska partykuła składa się z demonstratywnego $d$ (por. łac. idem, quidam) i końcówki deklinacyjnej - a (por. Kopečný i in., 1980, s. 151; Miklosich, 1886, s. 39; Skok, 1971, s. 370; Младенов, 1941, s. 210).

Według słowników pod redakcją Vostokova i Sławskiego da stanowi kontynuant greckiego iv $\alpha$ (por. Sławski, 1976, s. 324; Востоков, 1858, s. 97). Berneker (1908, s. 175-176) oraz autorzy słownika Bułgarskiej Akademii Nauk (Георгиев, 1977, s. 309-310) wskazują z kolei na $\delta \dot{~ / ~ \delta \alpha i ́ ~ o ~ z n a c z e n i u ~ z b l i z ̇ o n y m ~}$ do łacińskiego 'denique'. Odnotowane w słowniku prasłowiańskim de : dě ma zaś kontynuować indoeuropejskie $d e$ i odpowiadać greckiemu $-\delta \varepsilon$, które wyraża kierunek (Sławski, 1979, s. 26).

Omówione funkcje spójnikowe traktowane są jako wtórne i pochodzą $\mathrm{z}$,pierwotnych funkcji ekspresywnych partykuły wzmacniającej, potwierdzającej, modalnej, o charakterze optatywnym". Zaś funkcja spójnika hipotaktycznego ('żeby') powstała ze spójnika początkowo kopulatywnego o odcieniu życzącym (Sławski, 1976, s. 325).

\section{Dystrybucja i zakres użycia}

\subsection{Słowiańszczyzna zachodnia}

W Słowniku prasłowiańskim (Sławski, 1976, s. 323) powołano się na obecność da w staropolszczyźnie w 1437 roku, kiedy nosiło znaczenie 'niech', 'oby'. Było używane w niektórych dialektach w funkcji ekspresyjnej partykuły potwierdzająco-wzmacniającej i wykrzyknika; mogło też posiadać „niesprecyzowane bliżej znaczenie spójnikowe bliskie 'i’”, jak również znaczenie adwersatywne ('lecz', 'ale').

W słowniku wileńskim oprócz „głosu śpiewającego bez wyrażenia słów” opisano leksem da jako „godło dziecinne kłaniania się lub dziękowania”

4 Meillet i Vaillant zwracają uwagę na niejasne pochodzenie da (Meillet \& Vaillant, 1934, s. 487). 
albo „słowo przydatkowe niepotrzebne, używane szczególniéj na Żmudzi” (Da porzuć że. Da cóż robisz). Interesująca jest również interpretacja znaczenia jako 'mniejsza o to', 'niech tak będzie'. Autorzy posłużyli się przykładem: Nie wieliczka to zbroja, mówi, da dobreńka (Zdanowicz i in., 1861, s. 206).

Z kolei w słowniku warszawskim podano dwa użycia słowa da. Pierwsze - wykrzyknienie o znaczeniu 'ej!' lub 'oj' (Nie chodź tam, Wojciechu, rzekt Jakób. Da! - odpowiedział Wojciech i odszedł. Jużeści nie nasz, chłopaku, da nie nasz, i siwoszka masz, da i masz), a także rodzaj przyśpiewu. Jako drugie użycie autorzy proponują spójnik o znaczeniu 'a', 'no', 'ależ', 'i', 'ale', 'lecz', 'jednak'(Da ruszże ś. przecie! Da! Niech ryje, niechaj wyje. Siedzi da siedzi. Niewieliczka to zbroja, da dobreńka. Na wojenke jada, da ja nie pojadę) (por. Karłowicz i in., 1900, s. 419).

W języku staroczeskim da oznacza 'tak'; tworzy także złożenia spójników neda, leda. Natomiast w środkowych i południowych dialektach języka słowackiego przybiera formę $b a$ (wtedy 'nawet'); może być spójnikiem parataktycznym. Od XVII wieku tworzy zaimki i przysłówki nieokreślone: dakto ('ktokolwiek'), dakde ('gdzieś'); w dialektach wschodnich - da(s) ('może', 'prawdopodobnie'); w niektórych dialektach spełnia funkcję partykuły życzącej: Da tä Boh $z$ milosti na veky vytvoril! Ponadto $\mathrm{w}$ dialektach środkowosłowackich spełnia funkcję spójnika 'że' (No vid’ǐs, da musela si sa popálit') (Sławski, 1976, s. 323).

W języku dolnołużyckim da oznacza 'także', 'też' i spełnia funkcje partykuły pytajnej 'czy', 'czyż'. Również w złożeniach typu daniž ( $\left.{ }^{\star} d a-n i-z ̌ e\right)$ oznacza 'ani razu', 'ani nawet'. Formy daśi : daś ( $\left.{ }^{*} d a-t i\right)$ mają odpowiadać imperatywnemu 'niech', 'niechaj' (daśi jo - 'niech będzie') (Sławski, 1976, s. 323).

\subsection{Słowiańszczyzna południowa}

Użycie leksemu $d a$ w językach południowosłowiańskich (z wyłączeniem języka słoweńskiego ${ }^{5}$ ) zdecydowanie wykracza poza poziom spójnika czy partykuły twierdzącej. Pełni bowiem funkcję wykładnika optatywności

${ }^{5}$ Język słoweński zachował da głównie w funkcji spójnika i nie kontynuuje charakterystycznych dla języków południowosłowiańskich konstrukcji na zastąpienie bezokolicznika (por. Bajec i in., 1994, s. 112-113). Słoweńskie dà, oprócz spełniania funkcji partykuły potwierdzającej i wykrzyknienia, wyraża rozkaz, życzenie oraz pragnienie (Da ste mi zdravi! Da mi pri priči izgineš!). Z imperatywem staje się partykułą wzmacniającą: beži da! ('biegnijże!'), pojdi da! ('pójdźże!'). Jako spójnik wprowadza zdania celowe ('aby', ‘żeby'), dopełnieniowe ('że'), sposobu ('że', 'że aż', 'tak że'), przyczynowe ('ponieważ', 'bo'), przyzwolone ('chociaż', 'choć'), 
w wyrażeniach 'da + praes.' oraz przy zastępowaniu bezokolicznika (tzw. syntaktyczny bałkanizm).

W obrębie diasystemu serbsko-chorwackiego da spełnia wiele złożonych funkcji. Słownik prasłowiański wymienia funkcję wzmacniającą o różnych odcieniach znaczeniowych (np. w funkcji aseweratywnej). Poza spełnianiem funkcji twierdzącej (tu również dä lub dâ), wyraża zdziwienie, tryb życzący; może być użyte również jako wykrzyknienie, np. pod postacią dä w znaczeniu 'wio!' przy popędzaniu konia. Da jako spójnik parataktyczny występować miał tylko między XII a XVIII wiekiem, natomiast współcześnie obecny jest tylko w dialektach czakawskich i zachodniosztokawskich (Ne uvedi nas $v$ napast, da izbavi nas od neprijazni) (Sławski, 1976, s. 324).

W dialektach czakawskich (XV-XVII wiek) odnotowano formę dari (<daže i), która łączy się z przyimkiem do (dari do) oraz, rzadziej, z przyimkiem $u$ (dari $u$ ). W okresie między XVI a XVIII wiekiem poświadczono samodzielną formę dar o znaczeniu przysłówka 'przynajmniej', jak również formę däre klasyfikowaną jako spójnik przyczynowy 'ponieważ' (Sławski, 1979, s. 25). W słowniku Skoka (1971, s. 369) leksemy te uzupełnione są o formy däno i dànu (XV wiek) oraz dàsi (XVI wiek) ${ }^{6}$. Ponadto wymieniono formy dak oraz dake (XV i XVI wiek) oraz występującą regionalnie w Serbii formę dâko zilustrowaną przykładem dâko mu läknē do ùjutru ('ako mu bude lakše do ujutru').

Również słowniki języka chorwackiego w sposób obszerny opisują użycie da. Hasło da w Rječniku hrvatskoga jezika (Iveković \& Broz, 1901, s. 187-190) podzielone zostało na dwie części. Pierwsza dotyczy da jako spójnika, zaś druga - jako wykrzyknika.

warunkowe ('gdyby', 'jakby', 'jak gdyby'). W dialekcie prekmurskim i we wschodniej Styrii daže jako spójnik miało być realizowane w formie dàre (rotacyzm) i oznaczać 'kiedy'. W dialekcie rezjańskim dardu (<daže do) posiada znaczenie 'do', 'do tego czasu', 'do tego miejsca' (Sławski, 1979, s. 24-25; Toporišič i in., 2001, s. 440).

${ }^{6}$ W okresie od XII do XVIII wieku zaobserwować można obecność formy dâj (o znaczeniu 'przynajmniej'), która jako archaizm zachowała się w przysłowiach (np. ako je kolac, daj da je oštar). Natomiast w połączeniu z budi (dajbudi) jest obecna współcześnie u czakawców. Zdaniem Skoka połączenie z turcyzmem bar (dajbar; w XVII wieku poświadczono również formę dajbare) jest żywe już jedynie wśród mieszkańców Liki. Formę wyparła hybryda ko đoja, powstała z połączenia rodzimej partykuły ko $(<k a o)$ oraz tureckiego güya o znaczeniu 'tak jakby'/'jak gdyby' (Skok, 1971, s. 369).

7 To właśnie z form dak oraz dake ma pochodzić rumuńskie dacă (Skok, 1971, s. 369). Ponadto w Słowniku prasłowiańskim podkreśla się słowiańskie pochodzenie rumuńskich dar, dară ('ale', 'lecz', 'przeto', 'tedy', 'ależ!'), doar, doară ('tylko', 'przecież', 'może', 'a nuż') oraz litewskiego doža ('jednak', 'przecież') (por. Sławski, 1979, s. 25). 
W funkcji spójnika chorwackie $d a$ (znane również pod postacią d') może nosić znaczenie 'że', 'żeby', 'aby' (Kolika je od zlata džamija, d' u njoj klanja danaest Turaka), 'gdyby' (Da sam znao da će tako biti), 'a', 'więc' (Da kako je kad nije tako? Da šta je kad nije to?), 'jeśli' (Da ako udari kiša), 'prawie', 'dopiero' (Tek da skoči trideset Turaka da uhate starca igumana), 'oby', 'gdyby tylko' (Da bih znao i na kozi orati. Bogme, baba, idem da bih se i ne vratio), 'że' (Kaže sve kako je bilo i da ona hoće da pogje za ono momče); występuje ponadto w zdaniach optatywnych (Da si živ i zdrav! Kazaću ti, ali sam Bog da mi pomogne, drugi mi niko ne može pomoći), rozkazujących (Odmah da ideš kući! Sad da platiš čovjeku što si mu dužan), pytajnych (Da nije Turčin pod kapom? Zar da majka ostane i bez sina?), celowych (Za to se domaćica stara, ili somun tako da umijesi, da se ne poznaje...). Słownik podaje ponadto użycie da w takich w zdaniach jak Evo sad ću leći u sanduk pa da ti kažem za što sam se nasmejao. Natomiast s glagolom u odregjenu obliku može zamijeniti neodregjeni oblik njegov (np. Najposle mu dopusti otac da ide da uči zanat).

Autorzy hasła wyliczają również najczęstsze połączenia $d a \mathrm{z}$ innymi elementami, są to 'a da' (Hoću, Uso, a da kako ne ću), 'baš da' (Iščeraću ispod Beča Turke, baš da bi mu kćeri ne uzeo), 'kao da' (Uzmu na Božić sjekiru i zamahnu kao da posijeku voćku nerotkinju), 'kanda' (Kanda ga je rana na prudu izbljuala), 'makar da' (makar šta da ostaviš, ne će teknuti), 'nego da' (Šta ima bolje nego da dobijem dva života). Ponadto w pieśniach ludowych da używane bywa jako wyraz bez znaczenia, mający na celu zwiększenie liczny sylab w utworze (Jošt da eli mladi Ali paša...) (Iveković \& Broz, 1901, s. 187-190).

Słownik V. Anicia (1998, s. 139) wskazuje trzy funkcje da. Pierwsza to funkcja spójnika celowego, przyłączającego zdania przyczynowe, czasowe, skutkowe oraz warunkowe; wyraża życzenie, wprowadza pytanie, a także służy przytaczaniu cudzej wypowiedzi (neće doći jer da nema vremena). Co więcej, autor słownika wskazuje na charakterystyczne użycie $d a$ w połączeniach da vidim i da se sjetim. Znaczenie pierwszego sparafrazowano wyrażeniami želim vidjeti, pokaži(te) mi, pokušat ću, vidjet ću kako ide (funkcionira itd.), zaś drugiego - dok se sjetim, moram se sjetiti, neka se sjetim. Inne funkcje, jakie pełni $d a$ w języku chorwackim to m.in. partykuła potwierdzająca, wzmacniająca, wykrzyknik oraz spójnik 'niż' ( ja sam to postigao, da tko drugi) ${ }^{8}$.

Słowniki serbsko-chorwackie i serbskie w sposób zbliżony przedstawiają użycie $d a$ w obrębie diasystemu. Słownik pod redakcją Bakoticia (Бакотић,

${ }^{8}$ Por. także słownik pod redakcją J. Šonje (Šonje, 2000, s. 155). 
1937, s. 154-155) w szczegółowy sposób opisuje je jako spójnik i przysłówek. Łączy ono „два дела реченице, од којих сваки има свој глагол, и [...] указује на то да други део реченице зависи од првога (np. Хоћу да ми дођете. Хтео бих да ми то учините)"'. Ponadto да оznacza оно што се има радити или стане нечега (np. он има да испреписује старе листине). W słowniku Serbskiej Akademii Nauki i Sztuk (Пешикан i in., 1966, s. 1-4), słowniku Maticy z 1967 r. (Стевановић \& Јонке, 1967, s. 608), słowniku pod redakcją M. Jocić i V. Vasić (Jocić \& Vasić, 1988, s. 176) oraz w słowniku Maticy z 2007 r. (Вујанић \& Николић, 2007, s. 231) także nie wykazuje się znaczących różnic $\mathrm{w}$ użyciu $d a \mathrm{w}$ obrębie diasystemu ${ }^{10}$.

Analiza materiału zawartego w słownikach języka bułgarskiego i języka macedońskiego nasuwa stwierdzenie, że leksem $\partial a$ w tych językach spełnia bardzo zbliżone funkcje do tych, jakie znane są użytkownikom języków diasystemu serbsko-chorwackiego. Bułgarsko-macedońskie $\partial a$ zaklasyfikowano m.in. jako partykułę modalną o charakterze optatywnym, dubitatywnym. $\mathrm{Z}$ formami 2. os. sg. i pl. zastępuje imperativus. Ponadto uwydatnia wątpliwość czy niepewność. W języku bułgarskim $\partial a$ wzmacnia czas przyszły ${ }^{11}$, łącząc jego składniki (mе да пuma); może też wzmacniać przyimki (бeз дa, преди да, за да, ако и да, макар да, който и да е, какъвто и да е, как да е). Podobnie jak w językach diasystemu łączy ze zdaniem nadrzędnym prawie wszystkie typy zdań podrzędnych (por. Sławski, 1976, s. 325; Георгиев, 1977, s. 520-525; Геров, 1975, s. 267-270; Дювернуа, 1889, s. 443-450; Конески i in., 1979, s. 125).

\subsection{Słowiańszczyzna wschodnia}

Omawiana partykuła w języku staroruskim, rosyjskim, ukraińskim ( $m a)$ i białoruskim $(\partial b l)$ posiada znaczenie partykuły potwierdzającej. Ciekawa jest jego funkcja w niektórych dialektach rosyjskich, gdzie stoi „na końcu zdania z odcieniem wzmacniającym, nawiązującym, łączącym, zaś po czasownikach

9 Autorzy słownika nie utożsamiają tego przypadku ze zdaniami życzącymi typu Да Бог да! Да си ми здрав и весео!

10 Słownik żargonu języka serbskiego (Андрић, 2005, s. 150) dodatkowo wyróżnia da jako składnik wielu wyrażeń o charakterze życzącym, zwłaszcza w formie zaklinania się lub gdy są one nacechowane pejoratywnie: Да добијеш један (ако те тажем)! Да ми кева једе песак (ако те лажем)!

${ }_{11} \mathrm{Na}$ użycie da z czasem przyszłym zwracano również w słowniku Carskiej Akademii Nauk (Поленов i in., 1847, s. 304). 
w formie czasu przeszłego wyraża wątpliwość lub zaprzeczenie treści wyrażonej przez czasownik" (Ходил-да! - ничего не выходил). W języku ukraińskim $\partial a \mathrm{w}$ funkcji twierdzenia występuje rzadko, z kolei jako spójnik łączny czy przeciwstawny wypierane jest przez ma. Ponadto w niektórych dialektach, podobnie jak w języku słowackim, służy jako prefiks w zaimkach i przysłówkach nieokreślonych (Sławski, 1976, s. 325).

W języku rosyjskim partykuła tworzy postać nieokreśloną zaimka lub przysłówka xmo-de ('ktoś); w ukraińskim - деxmo ('ktoś'), деякий ('jakiś) czy декілька ('niewiele'); w białoruskim - дзе-які ('jakiš'). Z kolei w ukraińskich dialektach $\partial \epsilon$ ma stanowić „okrzyk powstrzymujący bodące się woły”.

Podobnie jak w przypadku języków zachodniosłowiańskich oraz języka słoweńskiego, także języki wschodniosłowiańskie zdają się nie kontynuować staro-cerkiewno-słowiańskiej partykuły w tak poliwalentny sposób, jak ma to miejsce w serbsko-chorwackim diasystemie oraz grupie bułgarsko-macedońskiej.

\section{Specyfika południowosłowiańskiego 'da'}

\section{1. 'Da + praes.' jako syntaktyczny bałkanizm}

Wyrażenia z użyciem $d a$ stanowią charakterystyczny element w językach południowosłowiańskich. Już ok. X-XI wieku zaobserwowano na materiale tekstów staro-cerkiewno-słowiańskich tendencję do zastępowania bezokolicznika taką konstrukcją (Минчева, 1987, s. 74-75). Z czasem na obszarze bułgarsko-macedońskim oraz we wschodnich dialektach języka serbsko-chorwackiego infinitivus zanikł, zaś na wybrzeżu Adriatyku pojawiły się nawet nowe konstrukcje typu nešto za jesti, za imati (np. trpit budem svake trude za imati raj nebeski). Zanik bezokolicznika to charakterystyczna cecha także innych języków bałkańskich, nie tylko słowiańskich. Stieber (1989, s. 191-192) mówi o tej tendencji również w językach dakorumuńskim, albańskim i greckim. Ogólnobałkański zatem proces zaniku bezokolicznika dał w językach południowosłowiańskich konstrukcje, których składnikiem jest morfem $d a$ oraz odpowiednie formy czasownika. Zastępowanie bezokolicznika w ten sposób stanowi w językach południowej Słowiańszczyzny syntaktyczny bałkanizm (Skok, 1971, s. 369; Конески, 1967, s. 150). 


\subsection{Problematyka 'da' $w$ języku chorwackim}

Raguž wyróżnia w swojej gramatyce (Raguž, 1997, s. 160-161) pięć rodzajów form chorwackiego czasownika: infinitiv $\left(-t i,-c^{12} i^{12}\right)$, vrijeme (prezent, aorist, imperfekt, perfekt, pluskvamperfekt, futur I, futur II), način (imperativ, kondicional I, kondicional II, optativ), prilog (prezentski, prošli) oraz pridjev (radni, trpni).

Wymieniony bezokolicznik stanowi interesujący element chorwackiej gramatyki. O ile bowiem gramatyki tego języka konsekwentnie uznają za infinitiv jedynie te formy, które zakończone są na - $t i$ lub -ći, o tyle język ten zna i toleruje bałkańską konstrukcję 'da + praes.', która „zamjenjuje infinitiv uz glavnu radnju za koju poticaj dolazi iz subiekta” (Anić, 1998, s. 139).

W przypadku czasowników modalnych, kiedy dopełnienie w bezokoliczniku wprowadzałoby dwuznaczność, oprócz zamiany czasownika htjeti na željeti, Raguž (1997, s. 161-197) proponuje konstrukcję z da:

Hoćeš li jesti? (znaczenie teraźniejsze)

Hoće li biti to da ćeš jesti? (znaczenie przyszłe) ${ }^{13}$.

Autor gramatyki dopuszcza taką zamianę w przypadku, gdy dopełnienie w zdaniu z czasownikiem htjeti odnosi się do innej osoby, niż nim wyrażonej, por.:

Hoćeš li da ti skuham čaj?

Ona hoće da joj kažeš o čemu se radi.

Neću da gubite vrijeme uzalud.

Jednakże w przypadku podanych powyżej przykładów nie można mówić o zamianie bezokolicznika, bowiem jego obecność nie byłaby możliwa (por. $d a$ w funkcji spójnika o znaczeniu 'żeby', 'aby'). Co innego w sytuacji, gdy ,je rječ o konkretnim, intencionalnim, voljnim radnjama u afirmacijama i negacijama", por.:

Ona hoće da te vidi večeras.

Oni neće da rade.

Mama, Seka neće da jede.

Hoćeš li da ti skuham kavu? (Raguž, 1997, s. 161).

12 Formy -ti/-ći bywają niekiedy zastępowane przez $-t /-c$.

13 Dwuznaczność wynika $\mathrm{z}$ faktu, że chorwackie hoćeš stanowi zarówno teraźniejszą formę czasownika o znaczeniu 'chcieć', jak i akcentowaną formę czasownika pomocniczego czasu przyszłego. Tak więc hoćeš li jesti? oznacza zarazem 'czy będziesz jeść?' i 'czy chcesz jeść?’. 
Przy okazji czasowników htjeti i željeti, warto zwrócić uwagę na formy wymienionego wcześniej trybu optatywnego, które Raguž opisuje również jako glagolski pridjev radni ${ }^{14}$ (z uwagi na identyczność formy). Ponieważ imiesłów ten $\mathrm{w}$ połączeniu $\mathrm{z}$ czasownikiem pomocniczym biti tworzy również perfekt, autor wyjaśnia różnicę między tym czasem a trybem życzącym, wskazując na brak czasownika pomocniczego $w$ formach optatywnych (jego pominięcie w przypadku czasu przeszłego jest możliwe jedynie niekiedy), por.:

Živio! / Živjeli! (vs živjeli su / živio je itd.)

Bog te blogoslavio!

Dobro nam došao!

Vrag te odnio!

Zdravi bili i veseli!

Bog ga poživio! (Raguž, 1997, s. 197).

Według autora treści optatywne wyrażane są najczęściej w 2.i 3. os. sg., zaś sam tryb życzący (realizowany w ramach znanych już form imiesłowu przeszłego) wiąże się w języku chorwackim z absolutna rzeczywistością, bowiem życzenie dotyczy momentu jego wypowiadania (Raguž, 1997, s. 419-421).

Innym sposobem na wyrażenie woli mają też być bałkańskie konstrukcje 'da + praes.' (Da mi to doneseš danas! Da mi se više ne motaš tuda oko mene!) oraz 'da + perf.' o nieco silniejszej ekspresji (Da si se odmah vratio! Da te tu više nisam vidio!). Mimo życzącego charakteru nie są one klasyfikowane jako željni način (Raguž, 1997, s. 218).

W gramatyce pod redakcją Barić i in. (1997, s. 515-521) w sposób odmienny przedstawiono chorwackie zdania $\mathrm{z} d a$, co $\mathrm{w}$ kwestii wyrażeń $\mathrm{z}$ bezokolicznikiem nie zawsze pokrywa się ze stwierdzeniami Raguža. Autorzy wyliczają różne typy zdań $s$ veznikom $d a$, pośród których możliwe są m.in. następujące:

s glagolima govorenja (Reći ću ti samo to da je izdaja slična kradi), osjećanja (Još se po nečemu vidi da vrag nije tako crn), duševnog satanja (Braća nisu voljela da se druži sa seljacima), s glagolima htijenja (Ja hoću da govorim s gospodinom Mikulićem. Nije više mogla da ustane), događanja (U mome redu počela da ludi) itp. (Barić i in., 1997, s. 515-521).

Na podstawie wymienionych przykładów widać, że konstrukcja 'da + praes.' mogłaby zamieniać bezokolicznik nie tylko w zaproponowanych przez Raguža sytuacjach.

14 Jest to imiesłów czasu przeszłego odpowiadający staro-cerkiewno-słowiańskiemu participium praeteriti (perfecti) activi II, tzw. participium -l-owe. 
Hrvatska gramatika również uznaje optativus jako kategorię gramatyczną języka chorwackiego. Podobnie jak u Raguža autorzy wymieniają formy imiesłowu przeszłego, np. živio, živjeli (Barić i in., 1997, s. 225-244) lub Bog mu oprostio vinskoj duši! (Katičić, 1991, s. 71).

Przy okazji rozważań na temat opisywanej kategorii gramatycznej interesujące wydaje się stwierdzenie Matasovicia (2008, s. 280-282), który przypomina, że już w języku staro-cerkiewno-słowiańskim funkcje imperatywu przejął optatyw. Mimo wyparcia trybu rozkazującego przez tryb życzący, niektóre formy indoeuropejskiego imperatywu mogły się zachować, czego przykładem może być słowiańskie $d a<$ ie. ${ }^{*} d e h$ (o znaczeniu 'daj!').

\subsection{Modalność woluntatywna}

Języki słowiańskie dysponują zazwyczaj trzema środkami wyrażania modalności, są to indicativus, imperativus oraz conditionalis; jedynie język bułgarski i język macedoński mają dodatkowo imperceptivus (Dalewska-Greń, 2002, s. 281) zbliżony do tureckiego trybu nieświadka (tzw. duyulan geçmiş zaman $)^{15}$.

Wspomniany słowiański imperativus (tworzony przy częściowym udziale partykuły $d a$ ) służy wyrażaniu rozkazu, który autorka Języków słowiańskich, podobnie jak przytaczany już Matasović, łączy z optatywem. Treści o charakterze życzącym i rozkazującym stanowią bowiem wespół modalność woluntatywną. Tak rozumiana modalność przedstawia stosunek mówiącego do treści wypowiadanego komunikatu, który Dalewska-Greń (2002, s. 281, 424) proponuje parafrazować jako chcę, aby coś się urzeczywistniło. Co więcej, poza dostępnymi predykatami modalnymi ('chcę', 'życzę sobie' itp.) czy też verbami dicendi ('kazać, 'rozkazać', 'polecić'), wszystkie języki słowiańskie mogą wyrażać rozkaz imperatywem, natomiast życzenie - za pomocą trybu przypuszczającego z morfemem $b(y): b i$, np.:

pol. Napiłbym się teraz kawy. Obyś wiedziała. Przychodziłbyś do nas częściej!

cz. Kéž by ses brzo vrátil!

głuż. Hdyž nož so to stało njeby!

ros. Хорошо бы прибавилось снежку!

15 Tryb nieświadka odpowiada częściowo polskim konstrukcjom typu 'mieć + inf.' (np. sprawca miał się oddalić z miejsca zdarzenia, które można parafrazować jako 'według otrzymanej informacji oddalił się z miejsca zdarzenia'). 
ukr. Хай би Ясногорська, шилившись над ним, перевязувала йомугарячу рану...

s./ch. Otišla bih u bioskop! Popila bih malo mleka!

słń. Delat bi šli, ne pa da prosjačite.

bułg. Бих отищла на кино. Бих испила малко мляко.

mac. Ех, кога би имал мрежа голема колку езерото! (Dalewska-Greń, 2002, s. 427-428)

Istotnym uzupełnieniem tych informacji jest stwierdzenie, że środki formalne przeznaczone do wyrażania życzenia i rozkazu najczęściej mieszają się z leksykalnymi wykładnikami pozostałych modalności. Bowiem „pomiędzy życzeniem a rozkazem rozciąga się cała skala znaczeń pośrednich, jak np. prośba, uprzejme polecenie, rada, perswazja, ostrzeżenie itp.” i często dopiero środki prozodyczne, kontekst czy etyka językowa decydują o właściwej ich interpretacji (Dalewska-Greń, 2002, s. 425-430).

\section{3.a. 'Da + praes.' jako wykładnik optatywności}

W obliczu przedstawionej charakterystyki tzw. modalności woluntatywnej należy stwierdzić, iż w językach diasystemu serbsko-chorwackiego oraz grupy bułgarsko-macedońskiej (które kontynuują konstrukcje 'da + praes.') nie tylko imiesłów czasu przeszłego z morfemem - $l$ - (jak podawali dotychczas Raguž, Katičić oraz autorzy gramatyki pod redakcją Barić i in.) czy też formy trybu przypuszczającego (jak zauważyła Dalewska-Greń) mogą stanowić modus optativus, lecz są to także niektóre zdania z 'da + praes.'. Pisze o tym m.in. Асенова (1989, s. 104-155), rozumiejąc dwojako sposób realizacji tego syntaktycznego bałkanizmu, mianowicie jako konstrukcje na zastąpienie bezokolicznika oraz jako te, które służą wyrażaniu treści optatywnych.

Użycie $d a \mathrm{w}$ funkcji partykuły życzącej potwierdził szeroko omówiony materiał słownikowy. Już w Słowniku prasłowiańskim zwrócono uwagę na modalność tej partykuły, wskazując na jej optatywny charakter (por. Sławski, 1976, s. 323).

H. Dalewska-Greń zauważa, że leksem ten jest elementem wspólnym dla południowej słowiańszczyzny w kontekście wyrażania życzeń i rozkazów. Autorka przywołuje następujące przykłady:

s./ch. Da je vojska pod oružjem, da zastave trepte, i ja, da svako jutro dižem utege da budem jak u nepoznatu svrhu.

słń. Da si mi pametna! Da mi ne pridete več pred oči! Da mi tega nisi več storil! Da si mi zginil spred oči!

bułg. Ти да мәлчиш! Марине, да проготвиш две каруии! Да не паднеш! mac. Да кажеш! Да одиме на прошетка! (Dalewska-Greń, 2002, s. 429). 
Obce językom nie-południowosłowiańskim 'da + praes.' stanowi kolejny wykładnik optatywności w diasystemie serbsko-chorwackim oraz grupie bułgarsko-macedońskiej.

\section{3.b. 'Da + perf.' jako życzenie w przeszłości}

Partykuła $d a \mathrm{w}$ połączeniu $\mathrm{z}$ formą czasownika w czasie przeszłym jest w językach diasystemu serbsko-chorwackiego składnikiem zdań warunkowych nierealnych i oznacza (z perspektywy mówiącego) czynność możliwą do spełnienia w przeszłości. Jednak nie jest to typowy dla języków słowiańskich sposób na wyrażanie modalności o charakterze prawdziwościowym, tj. „na skali zawartej pomiędzy biegunem 'Jest prawdą, że...' i biegunem odrzucającym asercję 'Jest nieprawdą, że...” (Dalewska-Greń, 2002, s. 411).

W języku prasłowiańskim conditionalis tworzony był przy użyciu odpowiedniej formy $b y t i^{16}$ i participium -l-owego. Taki typ trybu warunkowego zanika w zabytkach staro-cerkiewno-słowiańskich, a dawne bimı i bi zastąpione zostają

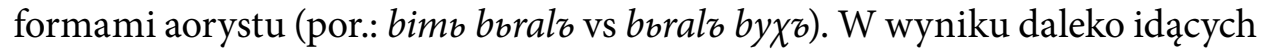
zmian formy te realizują się współcześnie nieco inaczej (por. pol. chciałbym, serb. xmeo биx, słc. volal by som, ukr. я ходив би), jednak oparte są na tym samym schemacie (Dalewska-Greń, 2002, s. 383; Stieber, 1989, s. 222-223).

Niemniej w językach południowosłowiańskich wykształciła się możliwość wyrażenia zdania warunkowego nierealnego przy udziale morfemu $d a$ oraz przeszłej formy czasownika, por.:

s./ch. Da si došao deset minuta ranije, imao bi mjesto.

mac. Да ми кажеше порано, немаше да има проблем itр.

W ten sposób zdania warunkowe nierealne z partykułą da stanowią swoistą parafrazę życzenia, które mogło mieć miejsce w przeszłości (np. 'Dođi ranije, imat ćeš mjesto'), ale o którym wiadomo z perspektywy czasu, że nie jest już możliwe do spełnienia.

\section{Podsumowanie}

$D a$ w językach słowiańskich stanowi złożony element mający wiele znaczeń i funkcji. Jako spójnik, wykrzyknik oraz partykuła bierze udział w tworzeniu niemal wszystkich możliwych typów zdań w zależności od zespołu językowego.

${ }^{16}$ O swoim własnym, niezłożonym conditionalis (Stieber, 1989, s. 222). 
Specyficzny charakter $d a$ wydaje się szczególnie widoczny na materiale języków diasystemu serbsko-chorwackiego oraz grupy bułgarsko-macedońskiej. Da pełni bowiem w tych językach funkcję partykuły ekspresywnej, wzmacniającej, uwydatniającej, potwierdzającej oraz woluntatywnej, stanowi element składowy życzeń oraz rozkazów; może być ponadto spójnikiem przeciwstawnym, łącznym, wprowadzać zdania celowe, skutkowe, przyczynowe i warunkowe. W odróżnieniu od pozostałych języków słowiańszczyzny, południowosłowiańskie $d a$ wchodzi w związek z czasownikiem, tworząc dystrybuowane na Bałkanach optatywne struktury syntaktyczne.

\section{BIBLIOGRAFIA}

Anić, V. (1998). Rječnik hrvatskoga jezika. Zagreb: Novi Liber.

Bajec, A., i in. (Red.). (1994). Slovar slovenskega knjižnega jezika. Ljubljana: ISJ ZRC SAZU.

Barić, E., i in. (Red.). (1997). Hrvatska gramatika. Zagreb: ŠK.

Berneker, E. (1908). Slavisches etymologisches Wörterbuch (T. 1). Heidelberg: Carl Winter.

Dalewska-Greń, H. (2002). Języki słowiańskie. Warszawa: PWN.

Iveković, F., \& Broz, I. (1901). Rječnik hrvatskoga jezika. Zagreb: Dominović.

Jocić, M., \& Vasić, V. (1988). Školski rečnik standardnog srpskohrvatskog/hrvatskosrpskog jezika (T. 1). Novi Sad: ZIU SRS.

Karłowicz, A., i in. (Red.). (1900). Stownik języka polskiego (T. 1). Warszawa: PIW.

Katičić, R. (1991). Sintaksa hrvatskoga književnog jezika. Zagreb: HAZU.

Kopečný, F., i in. (Red.). (1980). Etymologický slovník slovanských jazyků. Praha: Academia.

Matasović, R. (2008). Poredbenopovijesna gramatika hrvatskoga jezika. Zagreb: Matica Hrvatska. Meillet, A., \& Vaillant, A. (1934). Le slave commun. Paris: Champion.

Miklosich, F. (1886). Etymologisches Wörterbuch der slavischen Sprachen. Wien: Wilhelm Braumüller.

Raguž, D. (1997). Praktična hrvatska gramatika. Zagreb: Medicinska Naklada.

Sadnik, L., \& Aitzetmüller, R. (1955). Handwörterbuch zu den altkirchenslavischen Texten. Heidelberg: Carl Winter.

Skok, P. (1971). Etimologijski rječnik hrvatskoga ili srpskoga jezika (T. 1). Zagreb: JAZU.

Sławski, F. (Red.). (1976). Stownik prasłowiański (T. 2). Wrocław: Ossolineum.

Sławski, F. (Red.). (1979). Słownik prastowiański (T. 3). Wrocław: Ossolineum.

Stieber, Z. (1989). Zarys gramatyki porównawczej języków stowiańskich. Warszawa: PWN. 
Šonje, J. (Red.). (2000). Rječnik hrvatskoga jezika. Zagreb: LZ „Miroslav Krleža” i ŠK.

Toporišič, J., i in. (Red.). (2001). Slovenski pravopis. Ljubljana: ISJ ZRC SAZU.

Zdanowicz, A., i in. (Red.). (1861). Słownik języka polskiego. Wilno: Maurycy Orgelbrand.

Znosko, A. (1996). Słownik cerkiewnosłowiańsko-polski. Białystok: Prawosławna Diecezja Białostocko-Gdańska.

Андрић, Д. (2005). Двосмерни речник српског жаргона и жаргону сродних речи и израза. Београд: Zepter Book World.

Асенова, П. (1989). Балканско езикознание: Основни проблеми на балканския езиков съюз. София: Фабер.

Бакотић, Л. (Red.). (1937). Речник српскохрватског књижевног језика. Београд: ГЗ „Планета”.

Востоков, A. Х. (Red.). (1858). Словарь церковно-славянского языка. Санкт-Петербург: ИАН.

Вујанић, М., \& Николић, М. (Red.). (2007). Речник српскога језика. Нови Сад: Матица српска.

Георгиев, В. И. (Red.). (1977). Български етимологичен речник. София: БАН.

Геров, Н. (1975). Речник на българския език (Т. 1). София: Български писател.

Дювернуа, А. (1889). Словарь болгарского языка по памятникам народной словесности и произведениям новейшей печати (Т. 1). Москва: Университетская Типография.

Конески, Б. (1967). Историја на македонскиот јазик. Скопје: Култура.

Конески, Б., i in. (Red.). (1979). Речник на македонскиот јазик со српскохрватски толкувана. Скопје: ИМЈ „Крсте Мисирков”.

Минчева, А. (1987). Старобългарският език в светлината на балканистиката. София: Наука и Изкуство.

Младенов, С. (1941). Етимологически и правописен речник на българския книжовен език. София: Христо Г. Данов.

Пешикан, M., i in. (Red.). (1966). Речник српскохрватског кюижевног и народног језика (Т. 4). Београд: САНУ.

Поленов, В. Д., i in. (Red.). (1847). Словарь церковно-славянского и русского языка (Т. 1). Санкт-Петербург: ИАН.

Стевановић, М., \& Јонке, Љ. (Red.). (1967). Речник српскохрватскога књижевнога језика. Нови Сад: Матица српска. 


\section{BIBLIOGRAPHY}

\section{(TRANSLITERATION)}

Andrić, D. (2005). Dvosmerni rečnik srpskog žargona i žargonu srodnih reči i izraza. Beograd: Zepter Book World.

Anić, V. (1998). Rječnik hrvatskoga jezika. Zagreb: Novi Liber.

Asenova, P. (1989). Balkansko ezikoznanie: Osnovni problemi na balkanskiia ezikov sŭiuz. Sofiia: Faber.

Bajec, A., et al. (Eds.). (1994). Slovar slovenskega knjižnega jezika. Ljubljana: ISJ ZRC SAZU.

Bakotić, L. (Ed.). (1937). Rečnik srpskohrvatskog književnog jezika. Beograd: GZ "Planeta”.

Barić, E., et al. (Eds.). (1997). Hrvatska gramatika. Zagreb: ŠK.

Berneker, E. (1908). Slavisches etymologisches Wörterbuch (Vol. 1). Heidelberg: Carl Winter.

Dalewska-Greń, H. (2002). Języki słowiańskie. Warszawa: PWN.

Diuvernua, A. (1889). Slovar' bolgarskogo iazyka po pamiatnikam narodnoŭ slovesnosti i proizvedeniiam nove ̌she ̌ pechati (Vol. 1). Moskva: Universitetskaia Tipografiia.

Georgiev, V. I. (Ed.). (1977). Bŭlgarski etimologichen rechnik. Sofiia: BAN.

Gerov, N. (1975). Rechnik na bŭlgarskiia ezik (Vol. 1). Sofiia: Bŭlgarski pisatel.

Iveković, F., \& Broz, I. (1901). Rječnik hrvatskoga jezika. Zagreb: Dominović.

Jocić, M., \& Vasić, V. (1988). Školski rečnik standardnog srpskohrvatskog/hrvatskosrpskog jezika (Vol. 1). Novi Sad: ZIU SRS.

Karłowicz, A., et al. (Eds.). (1990). Słownik języka polskiego (Vol. 1). Warszawa: PIW.

Katičić, R. (1991). Sintaksa hrvatskoga književnog jezika. Zagreb: HAZU.

Koneski, B. (1967). Istorija na makedonskiot jazik. Skopje: Kultura.

Koneski, B., et al. (Eds.). (1979). Rečnik na makedonskiot jazik so srpskohrvatski tolkuvanja. Skopje: IMJ "Krste Misirkov".

Kopečný, F., et al. (Eds.). (1980). Etymologický slovník slovanských jazyků. Praha: Academia. Matasović, R. (2008). Poredbenopovijesna gramatika hrvatskoga jezika. Zagreb: Matica Hrvatska. Meillet, A., \& Vaillant, A. (1934). Le slave commun. Paris: Champion.

Miklosich, F. (1886). Etymologisches Wörterbuch der slavischen Sprachen. Wien: Wilhelm Braumüller.

Mincheva, A. (1987). Starobŭlgarskiiat ezikv svetlinata na balkanistikata. Sofiia: Nauka i Izkustvo.

Mladenov, S. (1941). Etimologicheski i pravopisen rechnik na bŭlgarskiia knizhoven ezik. Sofiia: Khristo G. Danov. 
Pešikan M., et al. (Eds.). (1966). Rečnik srpskohrvatskog književnog i narodnog jezika (Vol.4). Beograd: SANU.

Polenov, V.D., et al. (Eds.). (1847). Slovar' tserkovno-slavianskogo i russkogo iazyka (Vol. 1). Sankt-Peterburg: IAN.

Raguž, D. (1997). Praktična hrvatska gramatika. Zagreb: Medicinska Naklada.

Sadnik, L., \& Aitzetmüller, R. (1955). Handwörterbuch zu den altkirchenslavischen Texten. Heidelberg: Carl Winter.

Skok, P. (1971). Etimologijski rječnik hrvatskoga ili srpskoga jezika (Vol. 1). Zagreb: JAZU.

Sławski, F. (Ed.). (1976). Słownik prasłowiański (Vol. 2). Wrocław: Ossolineum.

Sławski, F. (Ed.). (1979). Słownik prasłowiański (Vol. 3). Wrocław: Ossolineum.

Stevanović, M., \& Jonke, L. (Eds.). (1967). Rečnik srpskohrvatskoga književnoga jezika. Novi Sad: Matica srpska.

Stieber, Z. (1989). Zarys gramatyki porównawczej języków słowiańskich. Warszawa: PWN.

Šonje, J. (Ed.). (2000). Rječnik hrvatskoga jezika. Zagreb: LZ „Miroslav Krleža” i ŠK.

Toporišič, J., et al. (Eds.). (2001). Slovenski pravopis. Ljubljana: ISJ ZRC SAZU.

Vostokov, A. K. (Ed.). (1858). Slovar' tserkovno-slavianskogo iazyka. Sankt-Peterburg: IAN.

Vujanić, M., \& Nikolić, M. (Eds.). (2007). Rečnik srpskoga jezika. Novi Sad: Matica srpska.

Zdanowicz, A., et al. (Eds.). (1861). Słownik języka polskiego. Wilno: Maurycy Orgelbrand.

Znosko, A. (1996). Słownik cerkiewnosłowiańsko-polski. Białystok: Prawosławna Diecezja Białostocko-Gdańska.

\section{Słowiańskie ‘da’ i jego bałkańska specyfika}

Niniejszy artykuł stanowi próbę uporządkowania wiedzy na temat słowiańskiego $d a$, jego derywatów oraz dystrybucji językowej ze szczególnym uwzględnieniem diasystemu serbsko-chorwackiego. Analizę przeprowadzono na materiale słownikowym począwszy od języka prasłowiańskiego. Głównym założeniem pracy jest optatywność południowosłowiańskiej partykuły $d a$, która składa się na tzw. syntaktyczny bałkanizm. W problematyce zagadnienia została zawarta interpretacja własna autora.

Słowa kluczowe: słowiańskie 'da', optativus, modalność woluntatywna, tryb życzący, diasystem serbsko-chorwacki, syntaktyczny bałkanizm, składnia bałkańska, liga bałkańska 


\section{The Slavic 'da' and its Balkan Peculiarities}

The aim of this article is the analysis of the Slavic 'da', its derivates and distribution, from Proto-Slavic to modern Slavic languages, with particular emphasis on the Serbo-Croatian diasystem. The main assumption made by the author is the optativity of the South Slavic 'da', which constitutes a so-called syntactic Balkanism. The present study offers a concise presentation of the Slavic 'da', including both the dictionary data and the author's own interpretation of the role of this grammatical particle in the South Slavic languages.

Keywords: Slavic 'da', optative mood, voluntative modality, optative mood, Serbo-Croatian diasystem, syntactic Balkanism, Balkan syntax, Balkan Linguistic League, Balkan Sprachbund

\section{Notka o autorze}

Maciej Mielnik (m.mielnik@istanbul.edu.tr) - slawista (specjalizacja: kroatystyka) i turkolog (UJ), doktorant Instytutu Badań Turkologicznych Uniwersytetu Stambulskiego. Lektor języka polskiego oraz wykładowca na stambulskiej slawistyce. Zainteresowania naukowe: językoznawstwo słowiańskie i jego problematyka w kontekście tureckim, polityka językowa, krytyczna analiza dyskursu.

Maciej Mielnik (m.mielnik@istanbul.edu.tr) - slavist and turkologist (Jagiellonian University), $\mathrm{PhD}$ candidate at the Institute of Turkic Studies, Istanbul University, and lecturer at the Slavic Studies Department, Istanbul University. Research interests: Slavic linguistics and its Turkish contexts, language policies, critical discourse analysis. 